\title{
MAGES ACQUISITION OF MULTIPHASE DISPERSIONS IN FERMENTATION PROCESSES
}

\author{
B. Taboada', P. Larralde², T. Brito ${ }^{3}$, L. Vega-Alvarado', R. Díaz, E. Galindo³ \& G. Corkidi' \\ ${ }^{1}$ Centro de Ciencias Aplicadas y Desarrollo Tecnológico, UNAM., \\ Apdo. Postal 70-186, México 04510, D.F. \\ ${ }^{2}$ Centro de Biotecnología del IPN, \\ Reynosa, Tamaulipas \\ ${ }^{3}$ Instituto de Biotecnología de la UNAM, \\ Av. Universidad 2001, Col. Chamilpa, Cuernavaca, Morelos, CP.62250, México. \\ E-mail: corkidi@sgima.ceingebi.unam.mx \\ Received: May $9^{\text {th }} 2001$ and accepted March $8^{\text {th }} 2002$
}

\section{ABSTRACT}

Multiphase mixing is a common operation in fermentation process. However, one of the main problemsforonline automatic monitoring of dispersions occurring in microbial cultures in a mechanically simed bioreactor, is the difficulty in acquiring images (in motion) clear enough to characterize its elements (mainlyair, water, oil and biomass) and their interactions during cultivation. Once the images to be analyzed have been acquired, other problems arise related to the complexity and diversity of objects/artifacts captured in the visual field. The heterogeneous transparency of some objects, low contrast and similarity between different classesof objects are, among others, major problems for the automation of image analysis procedures. The purpose of this work is to present a system that allows the on-line acquisition of images inside a mechanically stirred tank The images are digitally obtained by connecting a TV camera to a stereomicroscope. The scanning of the camera is synchronized to the flashing of a stroboscope, which acts as the light source and isequipped with a submergible probe. These illumination conditions allow obtaining high quality images that can be further analyzed to quantify size distributions of air bubbles and oil drops in multiphase dispersion, and to observe the dynamics of phase interactions (solid, liquid and gaseous) in a model culture.

\section{RESUMEN}

El mezclado de multifases es una operación común en el proceso de fermentación. Sin embargo, uno de los principales problemas que presenta la automatización del monitoreo en línea de lasdispersionesque ocumen dentro de un cultivo microbiano en un fermentador bajo condiciones de agitación mecánica, esla dificultad en la adquisición de imágenes (en movimiento) lo suficientemente claras que permitan caracterizar sus elementos (principalmente aire, agua, aceite y biomasa) y su interacción durante su cultivo. Una vezque las imágenes a ser analizadas han sido adquiridas, otro problema que se presenta está relacionado con la complejidad y diversidad de objetos/artefactos capturados en el campo visual. La transparencia heterogénea de algunos objetos, el bajo contraste y la similitud entre las diferentes clases de objetos son, entre otros, problemas mayores para la automatización de los procedimientos de análisis de imágenes. El objetivo de este trabajo es presentar un sistema que permite la adquisición de imágenes en línea de lo que ocume dentro de un tanque agitado mecánicamente. Las imágenes son digitalmente obtenidasmediante una cámara de TV conectada a un estereomicroscopio. El barrido de la cámara es sincronizado con la luzde un estroboscopio, el cual actúa como fuente de luz y está equipado con una sonda sumergible. Estas condiciones de luz permiten obtener imágenes de alta calidad que pueden posteriormente ser analizadas para cuantificarel tamaño de las distribuciones de burbujas de aire y gotas de aceite en una dispersión multifásica yobservar las dinámicas de las interacciones de las fases (sólida, liquida y gaseosa) en un cultivo.

KEMWORDS: Four-phase system, bubble sizes, drop sizes, image acquisition. 


\section{INTRODUCTION}

Fermentation industry currently produces a w ide range of products. Many industrial processes involve filamentous fungi, witch are cultivated for the production of important molecules such as enzymes, organic acids, antibiotics, and aroma compounds amongst others. Usually, this fermentation process entails the mixing of up to four phases [1]. Therefore, it is important to determine the influence of bioreactor operational parameters (stirring speed, impeller type, pow er draw $\mathrm{n}$, etc) over the efficiency of the phases dispersions and ultimately on cultures performance. How ever, few works have been published about the monitoring of the phases dispersion in these types of fermentation with the use of image processing. Some of the early studies were conducted by photographing the tank wall [2]. How ever, the analysis of photographs is a tedious and costly activity, involving a relatively long processing time period. Other approach has been the study of fungal grow th during the early grow th stages [3] by using a small grow th chamber, w hich is mounted on a microscope and periodically fed with medium. Although providing interesting results, grow th in this system occurs under conditions differing to those found inside a mechanically stirred bioreactor. Moreover, in situ microscopy has been usedfor the characterization of microbial cultures [4,5] and in model for phases fermentation systems [6], althoughno details have been reported about the difficulties in image acquisition. One of the main problems arising from automatic monitoring of multiphase fungal cultures in a bioreactor, is the difficulty of acquiring images in motion clear enough to characterize the elements involved in the culture (air, oil and biomass, all immersed in an aqueous solution of salts). On the other hand, the diversity and complexity of these objects, as w ell as the presence of artifacts, the heterogeneous transparency of someobjects, their bw contrast and similarity of classes complicate the automation of the image analysis process [7].

The purpose of this work is to present a system that allow s the on-line acquisition of images inside a mechanically stirred tank. The generated images can be further analyzed to quantify size distributions of air bubbles and oil drops in a multiphase dispersion, and to observe the dynamics of phase (solid, liquid and gaseous) interactions in a model culture.

\section{PROBLEMS WITH THE ACQUISITION OF IMAGES IN MOTION}

The acquisition of images in motion presents several difficulties. The most evident comes from the velocity of the particles being analyzed in contrast to the limitations of the sensors used tocapture such images. A standard video camera generates an interlaced image by scanning out 480 horizontal lines (American standard) over $1 / 30 \mathrm{sec}$. (tw o interlaced $1 / 60 \mathrm{sec}$ fields of 240 even and odd lines) [8]. This means that if the objects to be captured are moving faster than the scanning speed, the resulting image will be a blurred one (Fig. 1). Moreover, single objects may appear tw ice or overlapped due to the interlacing effect of the tw o $1 / 60 \mathrm{sec}$ fields. This phenomenon is typically observed for images taken inside of a stirred tank, even at low stirring speeds.

One solution to this problem could have been to utilize a high-speed video camera. How ever, such equipment could cost several thousands of dollars. Hence, the alternative $w$ as to use a conventional video camera synchronized to the flashing of a stroboscope. This type of illumination provided by the immersion of a narrow probe in the stirred tank, had allow ed to decrease the frame rate required for obtaining sharp and non-overlapped interlaced images. Moreover, heterogeneous transparency, diversity and low contrast betw een different classes of objects are, amongst others, serious problems for the automation of the image analysis process, specially when high oil and mycelia density are involved. Therefore, the high luminescence provided by the stroboscopic lighting also helped substantially to avoid this problem by diminishing field darkening. 

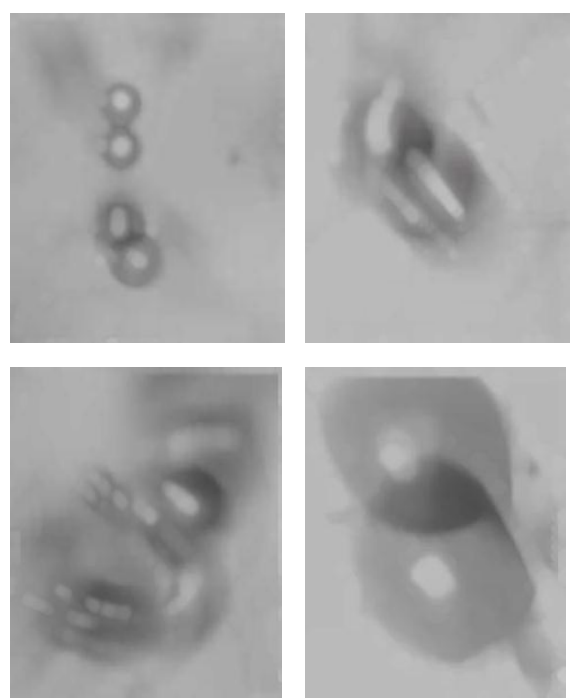

Figure 1. Examples of images of air bubbles captured without a stroboscopic light. Each one of these images show one bubble in motion, appearing as two overlapped or separated objects.

\section{SYSTEM DESCRIPTION}

\subsection{Optics}

A revolving nose-piece of an Olympus SZ-STU1 (SZ1145) stereomicroscope w as used to vary lens focal length. A magnification range from 1.8 to $11 \mathrm{X}$ w as covered from a relatively long distance of $110 \mathrm{~mm}$. This nose-piece w as mounted on an Olympus SZ-STB1ESD stand. Image acquisition w as achieved using a Hitachi KP-D50 Color NTSC digital video camera. The camera w as attached to the video tube of the stereomicroscope revolving nosepiece by means of an Olympus SZ-CTV coupling piece. A stroboscope (MNS-2600, EG\&G Optoelectronics) $w$ as used as the light source, connected $w$ ith ane meter long submergible fiber optic probe $w$ ith a $0.4 \mathrm{~mm}$ diameter $w$ indow light on its tip (Figure 2).

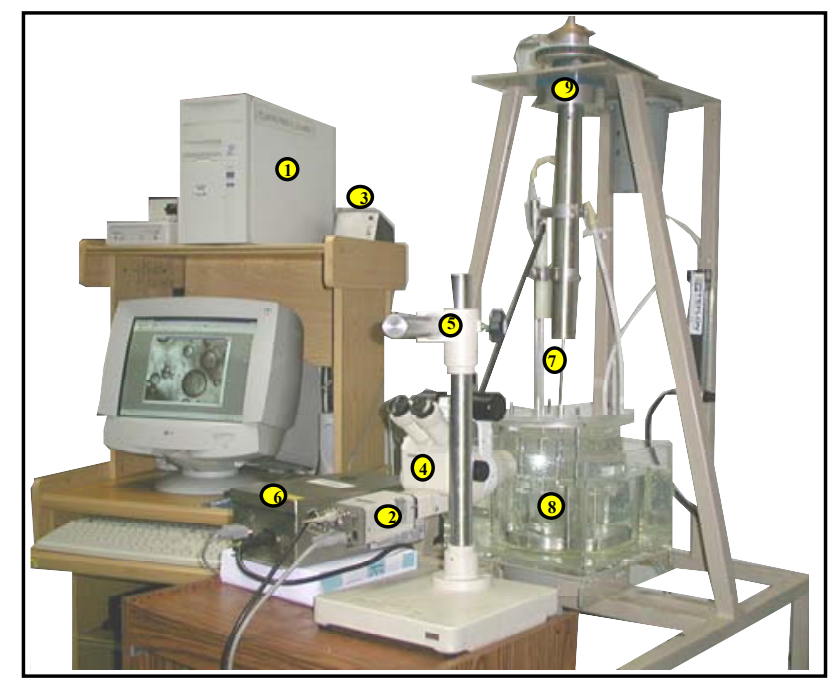

Figure 2. Photograph of the image acquisition system for the on-line capture of events occuringinside the stirred tank. 1) Computer with frame-grabber card and image analysis software. 2) Videocamera. 3) Video camera-stroboscope synchronization device. 4) Stereomicroscope revolving nosepiece. 5) Stand. 6) Stroboscopic light source. 7) Light robe. 8) Cylindrical stirred glass tank and square glass tank. 9) Agitation stand. 
Concerning the bioreactor, due to its cylindrical geometry, the objects (bubbles and drops) appear distorted (Figure 3 ) by the refraction on its curved $w$ all $w$ hen they are observed from outside (9). This w as overcome by placing the cylindrical tank inside of other transparent square tank that served as a curvature-correcting lens $w$ hen clear $w$ ater fills the space betw een the tw o tank.

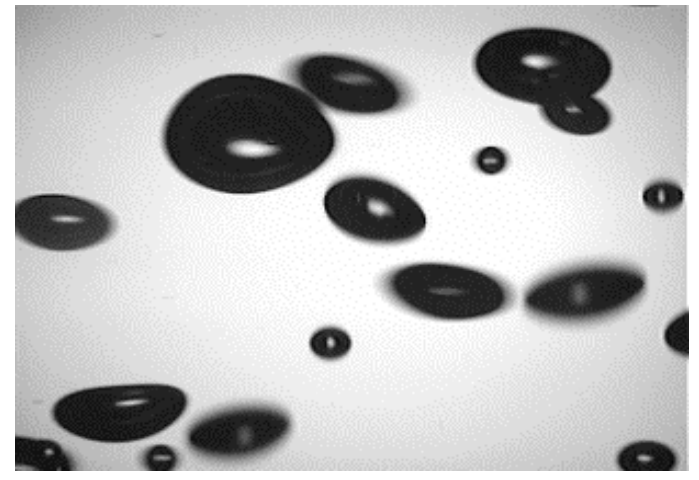

Figure 3. Example of bubbles image distorted by the refraction on the cylindrical tank. They were acquired using the synchronised camera-stroboscope system developed, but without placing the ellipsoidal stirred tank inside a square tank.

\subsection{Digital System}

A $733 \mathrm{MHz}$ Intel III processor (Intel Technologies) personal computer w as used. A Flash Point ${ }^{\circledR} 128$ (Integral Technologies) video capture card w as installed on the computer, providing the RBG/YCISYC input for the image acquisition and synchronization for the strobe triggering.

\subsection{Synchronizing System}

In order to obtain good quality images, it w as necessary to synchronise the stroboscope triggering with the vertical RBG/YC/SYNC signal of the video camera $[10,11]$, w hich w as externally coupled by a TTL inverting buffer. Moreover, in order to keep the flash lamp life, the pow er source of thestroboscope was controlled w ith a computer command, enabling flashing only in acquisition mode. For this purpose, itwas constructed an optical coupled interface that activates via the serial port, a mechanical relay providing AC source to the stroboscope. The light of the flashing pulses is sent via a submergible fbre optic probe inside the stirred tank.

\subsection{Software}

A C++ program w as $w$ ritten to enable stroboscope sw itching. The commercial softw are Image-ProPus v. 4.1 (Media Cybernetics, USA) w as used to create the subroutines (macros) needed to digitize and store images on the computer.

\section{RESULTS}

The synchronization of a conventional video camera $w$ ith the flashing of a stroboscope decreased the frame rate required to minimize the problem of overlapping objects and artifacts in a moving image. Besides, the high luminescence provided by the stroboscopic lighting helped to obtain sharp images as w ell as to diminish darkening of the visual field. By introducing the cylindrical stirred tank into a square tank filled w ith water, the ellipsoidal distortion of bubbles and drops w as eliminated. The necessary programs and subroutines were developed to acquire and store images as well as to sw itch the stroboscope. Figure 4 show s some examples of the types of images that can be obtained $w$ ith the developed system. 


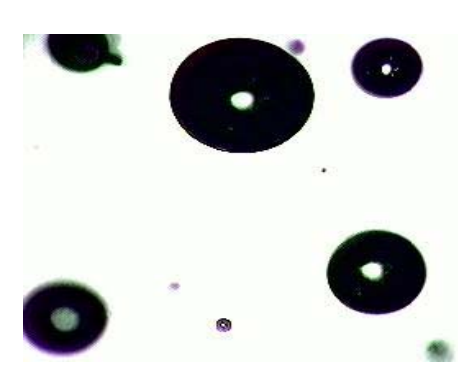

a)

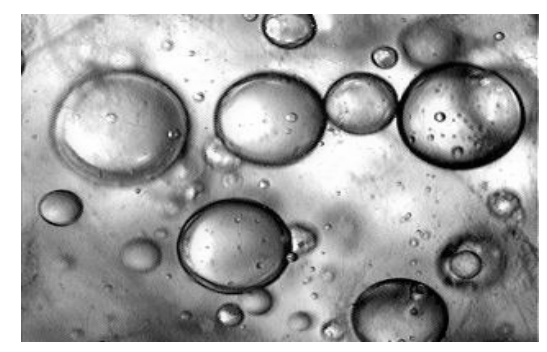

b)

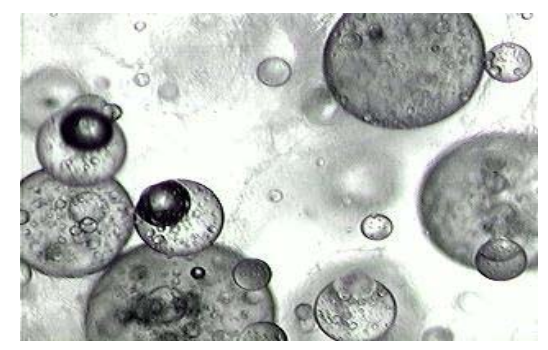

c)

Figure 4. Examples of images obtained using the fully implemented system. a) Airbubbles, b) Oil drops c) Oil drops and air bubbles.

\section{CONCLUSIONS}

An on-line image acquisition system $w$ as successfully coupled to a mechanically stirred tank Thequality of the images generated by the system allow s the quantification of the size distribution of oil drops and air bubbles in multiphase dispersions, as well as to make inferences about phase (solid, liquid and gaseous) interaction mechanisms in model and actual cultures. For the second stage, we are currenty developing algorithms for the automatic quantification of drop and bubble sizes, thereby saving time and effort to the researchers.

\section{REFERENCES}

[1] Cordova A.M.S., Sanchez A., Serrano C.L., Galindo E., 2001 Oil and Fungal Biomass Dispersion in Stirred Tank Containing a Simulated Fermentation Broth, J.Chem.Technal. Biotechnal, 76, 1101-1106.

[2] Chen H.T., Middleman S., 1967 "Drop Size Distributions in Stirred Liquid-liquid Systems", AIChE J, 13, (5), 989-998.

[3] Spohr A., Dam M.C., Carlsen M., Nielsen J., Villadsen J., 1998 On-line Study of Fungal Morphology During Submerged Grow th in a Small Flow -through Cell. Biotechnol, Bioeng. 58, (5), 541-553.

[4] Suhr H., Wehnert G., Schneider K., Bittner C., Scholz T., Geissler P., Jahne B., Scheper T., 1995 In Situ Microscopy for On-line Characterization of Cell-Populations in Bioreactors, Including CellConcentration Measurements by Depth from Focus" Biotechnol. Bioeng. 47, (1), 106-116.

[5] Dalmau E., Sánchez A., Montesinos J.L., Valero F., Lafuente F.J., Casas C., 1998 Study of Drop Size Distributions Frequencies in a Microbial Grow th System w ith an Aqueous-Organic Culture Medium: Lipase Production from Candida Rugosa, J. Biotechnol, 59,183-192.

[6] Galindo E, Pacek A.W., Nienow A.W., 2000 Study of Drop and Bubble Sizes in a Simulated Mycelia Fermentation Broth of up to Four Phases, Biotechnal. Bioing., 69, 213-121.

[7] Russ J.C, The Image Processing Handbook, 1992, CRC Press.

[8] Kenneth R.S., Fundamentals of Video Imaging, National High Magnetic Field Laboratory, Microscopy Premier.

[9] Hecht E., 1989 Optics, 2nd. Ed., Addison-Wesley, New York, N.Y.

[10] Manual of Hitachi KP-D50 Color NTSC Digital Video Camera.

[11] Manual of Stroboscope MVS-2600, EG\&G Optoelectronics. 
Authors Biography

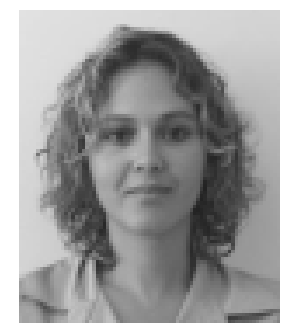

Blanca Taboada

A w as born in Cuernavaca, Morelos, México, in 1975. She graduated in Computer Science Engineering from the Instituto Tecnológico of Zacatepec (ITZ), Mexico, 1999. She is currently w orking in the Image and Vision Laboratory of the Centro de Ciencias Aplicadas y Desarrollo Tecnológico / Instituto de Biotecnología of the UNAM, Cuernavaca, Morelos, México. Her research interests include biomedical images processing, computer vision and pattern recognition.

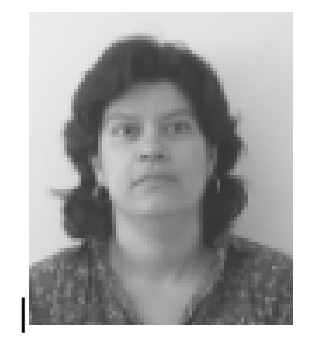

\section{Leticia Vega-Alvarado}

Was born in Mexico City, in 1969. She graduated in Applied Mathematics and Computing from the Universidad Nacional Autónoma de México (UNAM), Mexico, 1992, and got a Mater in Electrical Engineering from the Centro de Investigaciones Avanzadas(CINVESTAV-IPN), Mexico, 1996. She is $\mathrm{PhD}$ student at the Posgrado en Ciencias e Ingeniería de la Computación, UNAM. She is currently working in the Image and Vision Laboratory of the Centro de Ciencias Aplicadas y Desarrollo Tecnológico / Instituto de Biotecnología of the UNAM, Cuernavaca, Morelos, México. Her research interests include biomedical images processing, computer vision and pattern recognition.

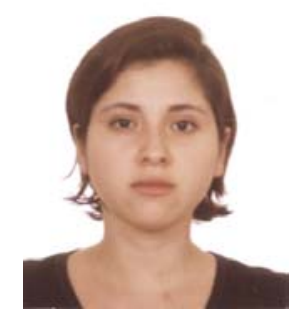

Teresa Brito

Was born in Cuernavaca, Morelos, México, in 1979. She graduated in Chemical Engineering from Universidad Autonoma del Estado de Morelos, 2001 (UAEM). She is a Master Student at Graduate Program in Biochemical Sciences/Institute of Biotechnology (UNAM, Cuernavaca, Mexico). Her research interests include the development of bioprocesses. 


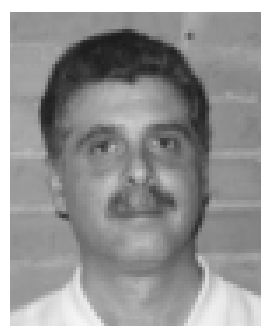

\section{Enrique Galindo}

Was born in Mexico City in 1957. He is a Chemical Engineer graduated (1979) from the University of Puebla (Mexico) and got a Master (1985) and PhD (1989) in Biotechnology from the National University of Mexico (UNAM). He is currently Professor at the Institute of Biotechnology (UNAM, Cuernavaca, Mexico), member of the National Researchers System (Mexico) and the Mexican Academy of Science. His research interests include the development and scale-up of bioprocesses and the hydrodynamics of multiphases fermentation systems.

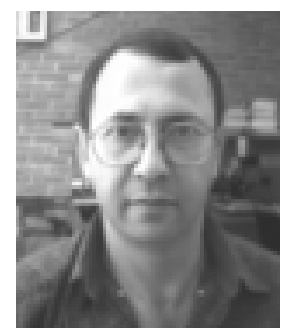

\section{Gabriel Corkidi}

Was born in Mexico City, in 1956. He graduated in Electronic Communication Engineering at the Universidad lberoamericana, Mexico City, 1980. He obtained his DEA and Doctorate from the Université de Paris XII in Biomedical Image Processing (Génie Biologique et Médical), in 1987 and 1989, respectively. He is currently the Head of the Image and Vision Laboratory of the Centro de Ciencias Aplicadas y Desarrollo Tecnológico / Instituto de Biotecnología of the UNAM, Cuernavaca, Morelos, México. His research interests include biomedical images processing, computer vision and pattern recognition. 